\title{
THE EFFECT OF SODIUM DODECYL SULPHATE ON THE FORCED HYDROLYSIS of $\mathrm{FeCl}_{3} \mathrm{SOLUTIONS}^{\bullet}$
}

\author{
Mira Ristić ${ }^{*}$, Jasenka Štajdohar ${ }^{1}$, Ivana Opačak ${ }^{2}$, Svetozar Musić $^{1}$ \\ ${ }^{1}$ Ruđer Bošković Institute, Zagreb, Croatia \\ ${ }^{2}$ Faculty of Science, University of Split, Croatia \\ e-mail: ristic@irb.hr
}

Precipitations by the forced hydrolysis of $0.2 \mathrm{M} \mathrm{FeCl}_{3}$ aqueous solutions between 2 and 72 hours in the presence of $1 \%$ sodium dodecyl sulphate (SDS) were investigated. In the absence of SDS a direct phase transformation $\beta-\mathrm{FeOOH} \rightarrow \alpha-\mathrm{Fe}_{2} \mathrm{O}_{3}$ via dissolution/recrystallization occured in the precipitation system. In the presence of SDS, $\alpha-$ $\mathrm{FeOOH}$ as an intermediate phase precipitated and, with a prolonged time of forced hydrolysis, also transformed to $\alpha-$ $\mathrm{Fe}_{2} \mathrm{O}_{3}$ via the dissolution/recrystallization mechanism. On the basis of Mössbauer spectra it was concluded that in the presence of SDS, $\alpha-\mathrm{Fe}_{2} \mathrm{O}_{3}$ phase possessed a lower degree of crystallinity. In this precipitation process the competition between the stability of Fe(III)-dodecyl sulphate, on one side, and the formation of iron oxide phases, on the other, also played an important role. FE SEM revealed that the big $\alpha-\mathrm{Fe}_{2} \mathrm{O}_{3}$ particles possessed the substructure. The elongation of primary $\alpha-\mathrm{Fe}_{2} \mathrm{O}_{3}$ particles produced in the presence of SDS was noticed. This effect can be assigned to the preferential adsorption of dodecyl sulphate groups on nuclei and crystallites of $\mathrm{FeOOH}$ and $\alpha-\mathrm{Fe}_{2} \mathrm{O}_{3}$ phase during the forced hydrolysis of $\mathrm{FeCl}_{3}$ solutions.

Key words: $\mathrm{FeCl}_{3}$ hydrolysis; sodium dodecyl sulphate; $\alpha-\mathrm{Fe}_{2} \mathrm{O}_{3}$; Mössbauer; FT-IR; XRD; FE SEM

\section{INTRODUCTION}

Hematite $\left(\alpha-\mathrm{Fe}_{2} \mathrm{O}_{3}\right)$ particles have found different applications as pigments, photocatalysts, electrode materials, fine abrasives or cosmetic additives. $\alpha-\mathrm{Fe}_{2} \mathrm{O}_{3}$ can also be used as an adsorbent for toxic elements or radioisotopes in wastewater treatment. In surface and colloid chemistry these particles are often used as model systems due to their excellent acido-basic surface properties. The investigation of colloid stability of $\alpha-\mathrm{Fe}_{2} \mathrm{O}_{3}$ particles is important for understanding the nature of this phenomenon.

The simplest way to produce $\alpha-\mathrm{Fe}_{2} \mathrm{O}_{3}$ particles is by forced hydrolysis in a boiling $0.01 \mathrm{M}$ $\mathrm{FeCl}_{3}$ solution [1], whereas at temperatures below $70{ }^{\circ} \mathrm{C}$ akaganéite $(\beta-\mathrm{FeOOH})$ particles (spindle- or cigar-shaped) will precipitate. The synthesis and characterization of $\beta-\mathrm{FeOOH}$ and its decomposition products in vacuum were investigated [2]. Musić et al. [3] used Mössbauer spectroscopy to investigate the hydrolysis of $0.1 \mathrm{M}$ solutions of $\mathrm{Fe}\left(\mathrm{NO}_{3}\right)_{3}, \mathrm{FeCl}_{3}$, $\mathrm{Fe}_{2}\left(\mathrm{SO}_{4}\right)_{3}$ or $\mathrm{NH}_{4} \mathrm{Fe}\left(\mathrm{SO}_{4}\right)_{2}$ at $90{ }^{\circ} \mathrm{C}$. A proposal was made concerning the mechanism of formation of the oxides and hydroxides of $\mathrm{Fe}^{3+}$ ions in these precipitation systems. It is generally accepted that the phase transformation $\beta-\mathrm{FeOOH} \rightarrow \alpha-\mathrm{Fe}_{2} \mathrm{O}_{3}$ in hydrolysing $\mathrm{FeCl}_{3}$ solutions at elevated temperature is operated by a dissolution/recrystallization mechanism [4-6]. The application of Mössbauer spectroscopy in investigating the precipitation of iron oxides has recently been reviewed by Musić et al. [7].

The nano/microstructure of $\alpha-\mathrm{Fe}_{2} \mathrm{O}_{3}$ plays a very important role in many applications of this iron oxide. For this reason many researchers investigated the conditions for the preparation of $\alpha$ $\mathrm{Fe}_{2} \mathrm{O}_{3}$ with different properties. Katsuki and Komarneni [8] used the forced hydrolysis of the $\mathrm{FeCl}_{3}$ solution under hydrothermal conditions to investigate the influence of morphology on the colour of 
the red pigment $\left(\alpha-\mathrm{Fe}_{2} \mathrm{O}_{3}\right)$ for porcelain. Sugimoto et al. [9] noticed remarkably different effects of $\mathrm{Cl}^{-}$, $\mathrm{OH}^{-}, \mathrm{SO}_{4}{ }^{2-}$ or $\mathrm{PO}_{4}{ }^{3-}$ anions on the shape and internal structure of $\alpha-\mathrm{Fe}_{2} \mathrm{O}_{3}$ particles. Hollow $\alpha-\mathrm{Fe}_{2} \mathrm{O}_{3}$ spheres were produced by the forced hydrolysis of the $\mathrm{FeCl}_{3}$ solution containing $\mathrm{H}_{3} \mathrm{PW}_{12} \mathrm{O}_{40}$ [10]. Mesoporous $\alpha-\mathrm{Fe}_{2} \mathrm{O}_{3}$ particles were produced by the forced hydrolysis of the $\mathrm{FeCl}_{3}$ solution containing L-phenylalanine and N-(3-di methylaminoethylaminopropyl)-N-ethylcarbodiimide hydrochloride [11]. Kandori et al. [12] also investigated the effect of surfactants on the precipitation of colloidal particles by the forced hydrolysis of the $\mathrm{FeCl}_{3}-\mathrm{HCl}$ solution. The hydrothermal transformation $\beta$-FeOOH $\rightarrow \alpha-\mathrm{Fe}_{2} \mathrm{O}_{3}$ in dense aqueous suspensions, prepared by a partial neutralization of the concentrated $\mathrm{FeCl}_{3}$ solution with the concentrated $\mathrm{NaOH}$ solution, was investigated by Žic et al. [13]. Žic et al. [14] also investigated the precipitation of $\alpha-\mathrm{Fe}_{2} \mathrm{O}_{3}$ from dense $\beta-\mathrm{FeOOH}$ suspensions with ammonium amidosulphonate added. The peanut-type $\alpha-\mathrm{Fe}_{2} \mathrm{O}_{3}$ particles, as well as particles in the form of double cupolas interconnected with the neck were obtained. These particles showed the substructure. Double cupolas were porous and consisted of linear chains of small $\alpha-\mathrm{Fe}_{2} \mathrm{O}_{3}$ particles (also interconnected) which were directed from the centre toward the surface of cupolas.

The aim of the present work was to obtain more data about the influence of sodium dodecyl sulphate on the crystallization kinetics, phase transformations and particle morphology in the precipitates formed by the forced hydrolysis of aqueous $\mathrm{FeCl}_{3}$ solutions. This work is a continuation of our longtime investigations in the precipitation chemistry of iron oxides (group name for hydroxides, oxyhydroxides and oxides). In many cases the phase analyses of solid hydrolytical products of iron ions are a demanding task, specifically if iron oxide phases vary from amorphous to a well-crystalline nature. For this reason three complementary tech- niques, ${ }^{57} \mathrm{Fe}$ Mössbauer, FT-IR and XRD were used in the phase analysis. Generally, it is known that surface active agents act very differently on the precipitation processes in dependence on their characteristics (polar, nonpolar, chemical nature of the organic chain, $\mathrm{pH}$ ).

\section{EXPERIMENTAL}

\section{Sample preparation}

AnalaR grade $\mathrm{FeCl}_{3} \cdot 6 \mathrm{H}_{2} \mathrm{O}$ was supplied by Kemika. Sodium dodecyl sulphate (SDS) was supplied by Sigma Aldrich (Cat. No.: 151-21-3; ACS grade reagent). Twice distilled water was prepared in own laboratory and used in all experiments. The stock solution $2 \mathrm{M} \mathrm{FeCl}_{3}$ was prepared. The concentration of $0.2 \mathrm{M} \mathrm{FeCl}_{3}$ was adjusted in all precipitation systems. The experimental conditions for the preparation of samples are given in Table 1. The yellowish precipitate was formed by adding $\mathrm{FeCl}_{3}$ solution into clear aqueous solution of SDS thus indicating the formation of $\mathrm{Fe}(\mathrm{III})$-dodecyl sulphate. Thus obtained suspension was homogenized in ultrasound bath. The precipitation systems were autoclaved at $160{ }^{\circ} \mathrm{C}$ using a Teflon ${ }^{\mathrm{R}}$-lined, nonstirred pressure vessel manufactured by Parr Instruments (model 4744). The autoclaves were heated between 2 and $72 \mathrm{~h}$ in a DX 300 gravity oven (Yamato; temperature uniformity $\pm 1.9{ }^{\circ} \mathrm{C}$ at $100{ }^{\circ} \mathrm{C}$ and $\pm 3{ }^{\circ} \mathrm{C}$ at $200{ }^{\circ} \mathrm{C}$ ). The autoclaving times were corrected for the time needed that the autoclave reaches the predetermined temperature. After a proper autoclaving time the autoclaves were abruptly cooled with cold water. The mother liquor was separated from the precipitate with the ultra-speed centrifuge (Sorvall model Super T21). The separated precipitates were subsequently washed with twice-distilled water and one time with $\mathrm{C}_{2} \mathrm{H}_{5} \mathrm{OH}$, then dried.

Table 1. Experimental conditions for forced hydrolysis of $0.2 \mathrm{M} \mathrm{FeCl}_{3}$ solution containing SDS

\begin{tabular}{cccccc}
\hline Sample & $\mathbf{2 M ~ F e C l}_{\mathbf{3}} / \mathbf{~ m l}$ & $\mathbf{S D S} / \mathbf{g}$ & $\mathbf{H}_{\mathbf{2}} \mathbf{O} / \mathbf{~ m l}$ & $\mathbf{T} / \mathbf{~}^{\mathbf{C}}$ & Time of ageing \\
\hline R1 & 4 & & 36 & 160 & $2 \mathrm{~h}$ \\
R2 & 4 & & 36 & 160 & $6 \mathrm{~h}$ \\
R3 & 4 & & 36 & 160 & $24 \mathrm{~h}$ \\
R4 & 4 & & 36 & 160 & $72 \mathrm{~h}$ \\
S1 & 4 & 0.4 & 36 & 160 & $2 \mathrm{~h}$ \\
S2 & 4 & 0.4 & 36 & 160 & $6 \mathrm{~h}$ \\
S3 & 4 & 0.4 & 36 & 160 & $24 \mathrm{~h}$ \\
S4 & 4 & 0.4 & 36 & 160 & $72 \mathrm{~h}$ \\
\hline
\end{tabular}

SDS $=$ sodium dodecyl sulphate $\mathrm{h}=$ hour 


\section{Instrumentation}

${ }^{57} \mathrm{Fe}$ Mössbauer spectra were recorded at 20 ${ }^{\circ} \mathrm{C}$ in the transmission mode using a standard configuration by WissEl GmbH (Starnberg, Germany). The ${ }^{57} \mathrm{Co} / \mathrm{Rh}$ Mössbauer source was used. The velocity scale and Mössbauer parameters refer to the metallic $\alpha$-Fe source at $20{ }^{\circ} \mathrm{C}$. Deconvolution of Mössbauer spectra was made using the MossWin program.

FT-IR spectra were recorded at RT with a Perkin-Elmer spectrometer (model 2000). The powders were mixed with $\mathrm{KBr}$, then pressed into tablets using the Carver press.

XRD patterns were recorded with an APD 2000 powder diffractometer manufactured by ItalStructures (GNR Analytical Instruments Group, Italy).

The samples were also inspected with a thermal field emission scanning electron microscope (FE SEM, model JSM-7000F) manufactured by Joel Ltd.

\section{RESULTS AND DISCUSSION}

The Mössbauer spectra of reference samples $\mathrm{R} 1$ to $\mathrm{R} 4$ as well as $\mathrm{S} 1$ to $\mathrm{S} 4$ produced in the presence of SDS surfactant are shown in Figures 1 and 2. The Mössbauer spectrum of sample R1 shows the superposition of two doublets with quadrupole splittings $\Delta_{1}=0.55$ and $\Delta_{2}=0.99 \mathrm{~mm} \mathrm{~s}^{-1}$. The pa- rameters of this spectrum can be assigned to $\beta$ $\mathrm{FeOOH}$ (Table 2). The spectra of samples R2, R3 and $\mathrm{R} 4$ are characterized by one sextet with parameters corresponding to $\alpha-\mathrm{Fe}_{2} \mathrm{O}_{3}$. The increase in hyperfine magnetic field (HMF) from 51.2 to 51.5 $\mathrm{T}$ with the autoclaving time prolonged from 6 and $72 \mathrm{~h}$ can be related to crystalline ordering in $\alpha$ $\mathrm{Fe}_{2} \mathrm{O}_{3}$. Upon $2 \mathrm{~h}$ forced hydrolysis of the $0.2 \mathrm{M}$ $\mathrm{FeCl}_{3}$ solution containing SDS surfactant (sample S1) a central quadrupole doublet was recorded. This spectrum was fitted for one average doublet with $\Delta=0.79 \mathrm{~mm} \mathrm{~s}^{-1}$ and can be assigned to $\beta$ $\mathrm{FeOOH}$. The effect of SDS added to the phase composition of a solid hydrolytical product is well visible in the spectrum of sample $\mathrm{S} 2$. This spectrum was fitted as a superposition of the central quadrupole doublet and two sextets. The central quadrupole doublet $\left(\Delta=0.75 \mathrm{~mm} \mathrm{~s}^{-1}\right)$ can be assigned to $\beta$-FeOOH (39 \%), whereas two sextets with $\mathrm{HMF}_{\text {average }}=48.5 \mathrm{~T}(\sim 56 \%)$ and $\mathrm{HMF}=37.4 \mathrm{~T}(5$ $\%$ ) can be assigned to $\alpha-\mathrm{Fe}_{2} \mathrm{O}_{3}$ and $\alpha-\mathrm{FeOOH}$ (goethite), respectively. The spectrum of sample S3 showed two sextets, one corresponding to $\alpha-\mathrm{Fe}_{2} \mathrm{O}_{3}$ $\left(\mathrm{HMF}_{\text {average }}=49.8 \mathrm{~T}\right)$ and the other of small relative intensity due to the presence of a small amount of $\alpha-\mathrm{FeOOH}$ (outer peaks in the spectrum denoted with arrows). Sample S4 showed only the presence of the $\alpha-\mathrm{Fe}_{2} \mathrm{O}_{3}$ phase characterized by $\mathrm{HMF}_{\text {average }}=$ $50.7 \mathrm{~T}$.

Table 2. ${ }^{57} \mathrm{Fe}$ Mössbauer parameters for samples R1 to R4 and S1 to S4

\begin{tabular}{|c|c|c|c|c|c|c|c|}
\hline Sample & Line & $\delta / \mathrm{mm} \mathrm{s}^{-1}$ & $\Delta$ or $E_{q} / \mathrm{mm} \mathrm{s}^{-1}$ & HMF / T & $\Gamma / \mathrm{mm} \mathrm{s}^{-1}$ & $A / \%$ & Identification \\
\hline \multirow[t]{2}{*}{ R1 } & Q1 & 0.38 & 0.55 & & 0.30 & 57 & \multirow{2}{*}{$\beta-\mathrm{FeOOH}$} \\
\hline & Q2 & 0.37 & 0.99 & & 0.33 & 43 & \\
\hline R2 & M & 0.37 & -0.21 & 51.2 & 0.34 & 100 & $\alpha-\mathrm{Fe}_{2} \mathrm{O}_{3}$ \\
\hline R3 & M & 0.36 & -0.21 & 51.5 & 0.29 & 100 & $\alpha-\mathrm{Fe}_{2} \mathrm{O}_{3}$ \\
\hline R4 & M & 0.37 & -0.21 & 51.5 & 0.34 & 100 & $\alpha-\mathrm{Fe}_{2} \mathrm{O}_{3}$ \\
\hline $\mathrm{S} 1$ & $\mathrm{Q}^{*}$ & 0.38 & 0.79 & & 0.23 & 100 & $\beta-\mathrm{FeOOH}$ \\
\hline \multirow[t]{3}{*}{$\mathrm{S} 2$} & $Q^{*}$ & 0.38 & 0.75 & & 0.54 & 39 & $\beta-\mathrm{FeOOH}$ \\
\hline & M1 & 0.37 & -0.26 & 37.4 & 0.97 & 5 & $\alpha-\mathrm{FeOOH}$ \\
\hline & M2 & 0.37 & -0.20 & 48.5 & 0.31 & 56 & $\alpha-\mathrm{Fe}_{2} \mathrm{O}_{3}$ \\
\hline S3 & M & 0.37 & -0.21 & 49.8 & 0.27 & 100 & $\alpha-\mathrm{Fe}_{2} \mathrm{O}_{3}{ }^{* *}$ \\
\hline S4 & M & 0.37 & -0.21 & 50.7 & 0.25 & 100 & $\alpha-\mathrm{Fe}_{2} \mathrm{O}_{3}$ \\
\hline
\end{tabular}

All data are given relative to $\alpha$-Fe standard.

Key: $\delta=$ isomer shift; $\Delta$ or $E q=$ quadrupole splitting; $\mathrm{HMF}=$ hyperfine magnetic field;

$\Gamma=$ line width; $A=$ area under the peaks

Errors: $\delta= \pm 0,01 \mathrm{~mm} \mathrm{~s}^{-1} ; \Delta$ or $E q= \pm 0,01 \mathrm{~mm} \mathrm{~s}^{-1}, \mathrm{HMF}= \pm 0,2 \mathrm{~T}$

*Average quadrupole doublet

${ }^{* *}$ Sample $\mathrm{S} 3$ also contains small amount of $\alpha-\mathrm{FeOOH}$, as denoted with arrows in Figure 2 


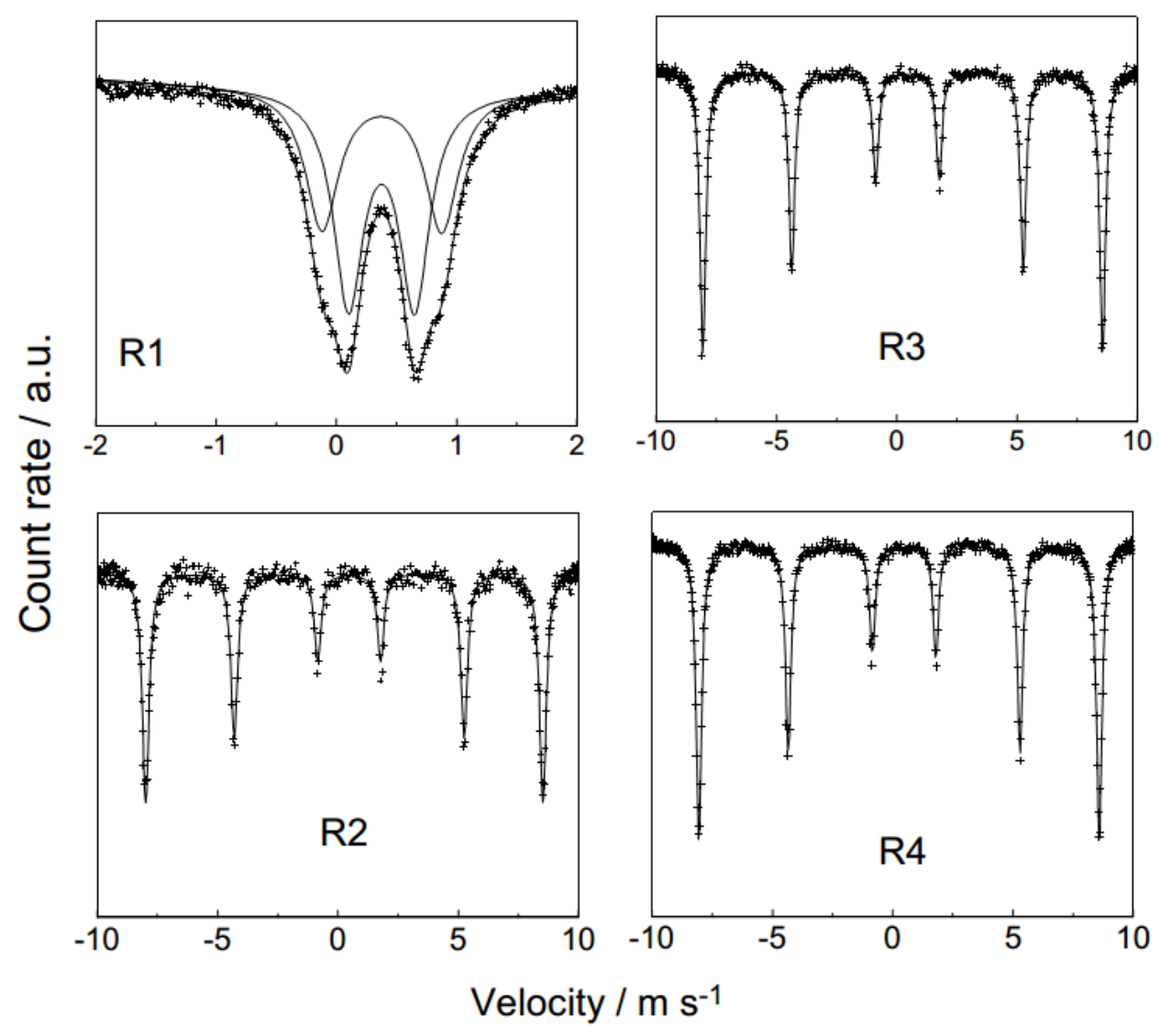

Figure 1. ${ }^{57} \mathrm{Fe}$ Mössbauer spectra of reference samples R1 to R4 produced by forced hydrolysis of $0.2 \mathrm{M} \mathrm{FeCl}_{3}$ solution in the presence of $1 \%$ SDS.

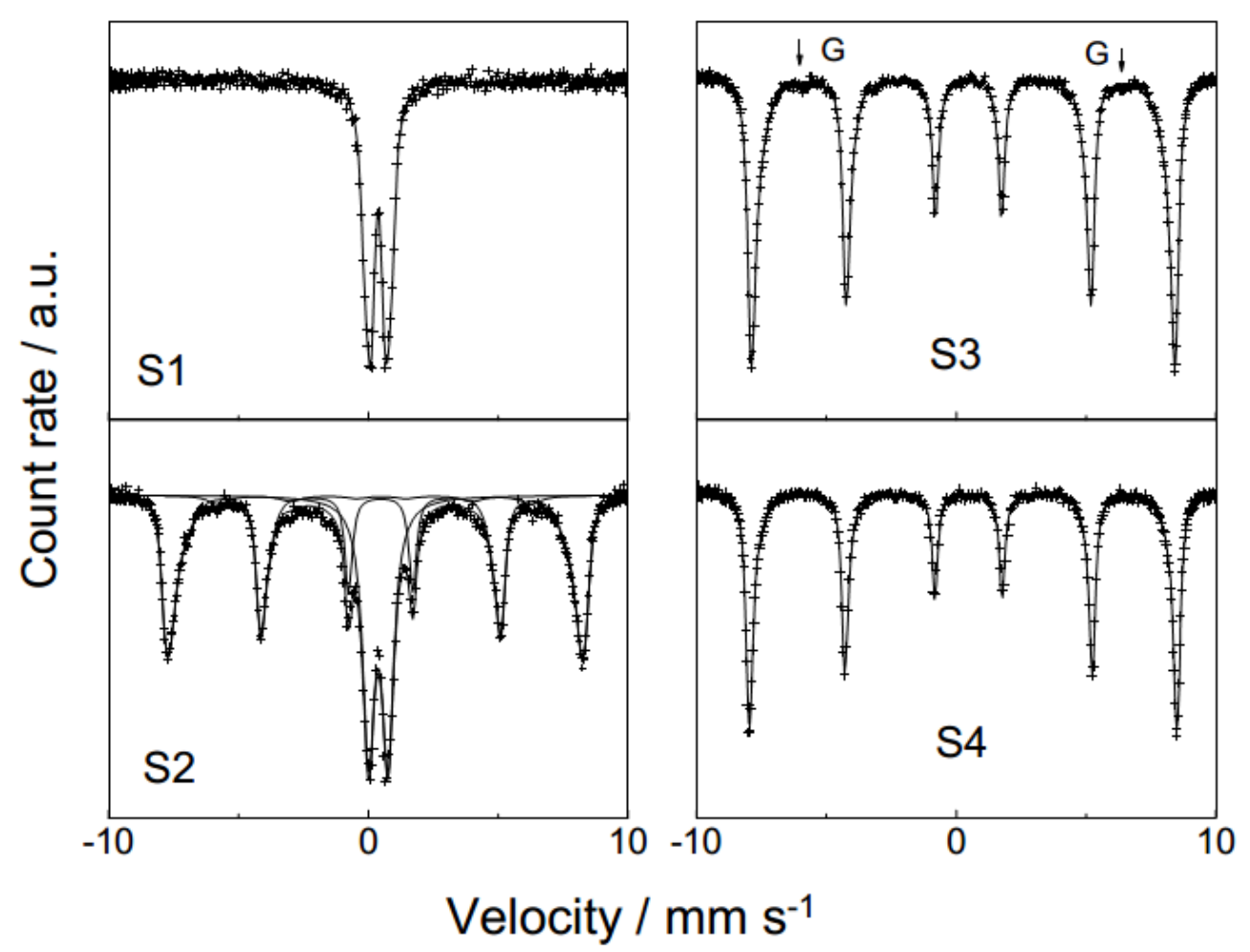

Figure 2. ${ }^{57} \mathrm{Fe}$ Mössbauer spectra of samples $\mathrm{S} 1$ to $\mathrm{S} 4$ produced by forced hydrolysis of $0.2 \mathrm{M} \mathrm{FeCl}_{3}$ solution in the presence of $1 \% \mathrm{SDS}$. 
The Mössbauer spectra of samples S1 and S2 were recorded at extended velocity scale and for this reason the central quadrupole splitting subspectrum was fitted for one average spectrum which is assigned to $\beta-\mathrm{FeOOH}$. The presence of $\beta-\mathrm{FeOOH}$ phase in samples $\mathrm{S} 1$ and $\mathrm{S} 2$ is confirmed with XRD as shown in Figure 3. The HMF values of $\alpha-\mathrm{Fe}_{2} \mathrm{O}_{3}$ calculated for samples S2 to S4 increased from 48.5 to $50.7 \mathrm{~T}$, which are lower values than those corresponding to $\alpha-\mathrm{Fe}_{2} \mathrm{O}_{3}$ for reference samples $\mathrm{R} 2$ to R4. Evidently, this effect can be assigned to the presence of SDS. The XRD patterns of $\mathrm{R}$ and $\mathrm{S}$ samples are given in Figure 3.

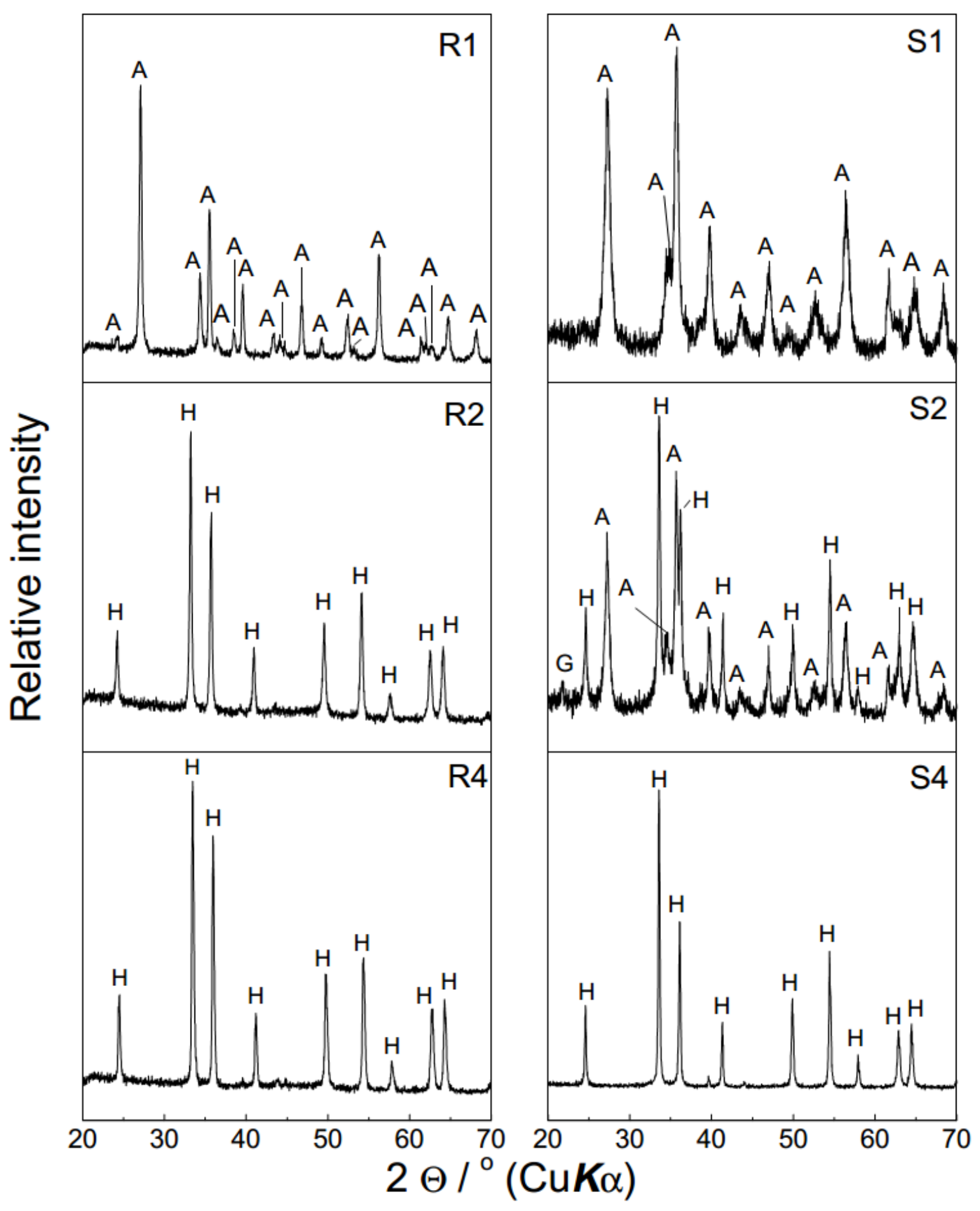

Figure 3. XRD patterns of reference samples R1, R2, R4 and samples S1, S2 and S4 produced in the presence of $1 \% \operatorname{SDS}$ ( $\mathrm{A}=$ Akagenéite; $\mathrm{G}=$ Goethite; $\mathrm{H}=$ Hematite). 
The sharpness of XRD lines of sample R1 (Figure 3) is increased in relation to sample S1 and this can be related to better crystallinity or an increased crystallite size of $\beta-\mathrm{FeOOH}$ precipitated in the absence of SDS. However, sample S1 as well as S2 showed a higher relative intensity of the diffraction line 211 in relation to line 310 , which could be related to the preferential adsorption of dodecyl sulphate groups on the selected crystallographic plane of $\beta-\mathrm{FeOOH}$. The XRD pattern of sample S2 showed a small relative intensity XRD line 110 (denoted as $G$ ) due to the presence of a small amount of goethite, and this is in line with corresponding Mössbauer spectrum.

Figure 4 shows the FT-IR spectra of reference samples R1 to R4 and samples $\mathrm{S} 1$ to $\mathrm{S} 4$ prepared in the presence of SDS. The FT-IR spectra of samples $\mathrm{R} 1$ and $\mathrm{S} 1$ can be assigned to $\beta-\mathrm{FeOOH}$. Sample R1 shows an IR band centred at $848 \mathrm{~cm}^{-1}$, two shoulders at 700 and $640 \mathrm{~cm}^{-1}$ and two shoulders at 498 and $425 \mathrm{~cm}^{-1}$. Sample S1 shows an IR band at $425 \mathrm{~cm}^{-1}$ with a shoulder at $491 \mathrm{~cm}^{-1}$. According to earlier work [15] the band at $848 \mathrm{~cm}^{-1}$ and the shoulder at $700 \mathrm{~cm}^{-1}$ can be assigned to the deformation vibration of $\mathrm{OH}$ groups, whereas the intense shoulder at $640 \mathrm{~cm}^{-1}$ can be related to the interaction of $\mathrm{Fe}-\mathrm{OH}$ groups with $\mathrm{Cl}^{-}$ions. Generally, $\beta$-FeOOH possesses a hollandite-type crystal structure and the structural channels in $\beta-\mathrm{FeOOH}$ produced from the $\mathrm{FeCl}_{3}$ solution contain water and a small amount of $\mathrm{Cl}^{-}$ions [16]. These $\mathrm{Cl}^{-}$ions (less than $\sim 2 \%$ ) in structural channels stabilize the crystal lattice of $\beta-\mathrm{FeOOH}$ and cannot be removed by simple washing. Weckler and Lutz [17] discussed two sets of vibrations at 847 and $820 \mathrm{~cm}^{-1}$, and also those at 697 and $644 \mathrm{~cm}^{-1}$ in terms of two $\mathrm{O}-\mathrm{H} . . . \mathrm{Cl}$ hydrogen bonds present in $\beta-\mathrm{FeOOH}$. The IR spectrum of $\beta$-FeOOH was also the subject of discussion by Murad and Bishop [18]. The FT-IR spectra of samples R2 to R4 can be assigned to $\alpha$ $\mathrm{Fe}_{2} \mathrm{O}_{3}$. Wang et al. [19] tabulated optical parameters for bulk $\alpha-\mathrm{Fe}_{2} \mathrm{O}_{3}$ and investigated the influence of the geometrical shape of $\alpha-\mathrm{Fe}_{2} \mathrm{O}_{3}$ particles on the corresponding FT-IR spectrum. Generally, the IR spectrum of $\alpha-\mathrm{Fe}_{2} \mathrm{O}_{3}$ shows six active vibrations, two $A_{2 \mathrm{u}}(\mathrm{E} \| \mathrm{C})$ and four $E_{\mathrm{u}}(\mathrm{E} \perp \mathrm{C})$. The effect of SDS is clearly visible in the spectra of samples S2 to S3. In the FT-IR spectrum of sample S2 the IR bands at 850, 697 and $640 \mathrm{~cm}^{-1}$ are due to $\beta$-FeOOH and the IR bands at 574, 537 and 482 $\mathrm{cm}^{-1}$ are due to $\alpha-\mathrm{Fe}_{2} \mathrm{O}_{3}$. Two IR bands at 895 and $796 \mathrm{~cm}^{-1}$ are typical of $\alpha-\mathrm{FeOOH}$ and are assigned to the $\mathrm{Fe}-\mathrm{O}-\mathrm{H}$ bending vibration $\left(\delta_{\mathrm{OH}}\right.$ and $\gamma_{\mathrm{OH}}$, re- spectively) [20]. The FT-IR spectrum of sample S3 shows only the presence of $\alpha-\mathrm{Fe}_{2} \mathrm{O}_{3}$ and a small fraction of $\alpha-\mathrm{FeOOH}$, whereas the FT-IR spectrum of sample $\mathrm{S} 4$ can be assigned to $\alpha-\mathrm{Fe}_{2} \mathrm{O}_{3}$ as a single phase. In the FT-IR spectra of samples produced in the presence of SDS additional bands are also noticed. For example, in the spectrum of sample S3 four IR bands at 1206, 1126, 1036 and $977 \mathrm{~cm}^{-1}$ are well visible. These IR bands can be related to the sulphate group. The $v_{3}\left(\mathrm{SO}_{4}\right)$ fundamental vibration is split into 3 active IR bands due to the formation of a surface bidentate bridging complex between the sulphate group and surface iron atoms [21]. The presence of an IR band at $977 \mathrm{~cm}^{-1}$ is due to the $v_{1}\left(\mathrm{SO}_{4}\right)$ vibration. It is generally known that the specific adsorption of oxyanions reaches its maximum at acidic $\mathrm{pH}$ values and decreases with an increase in $\mathrm{pH}$ values.

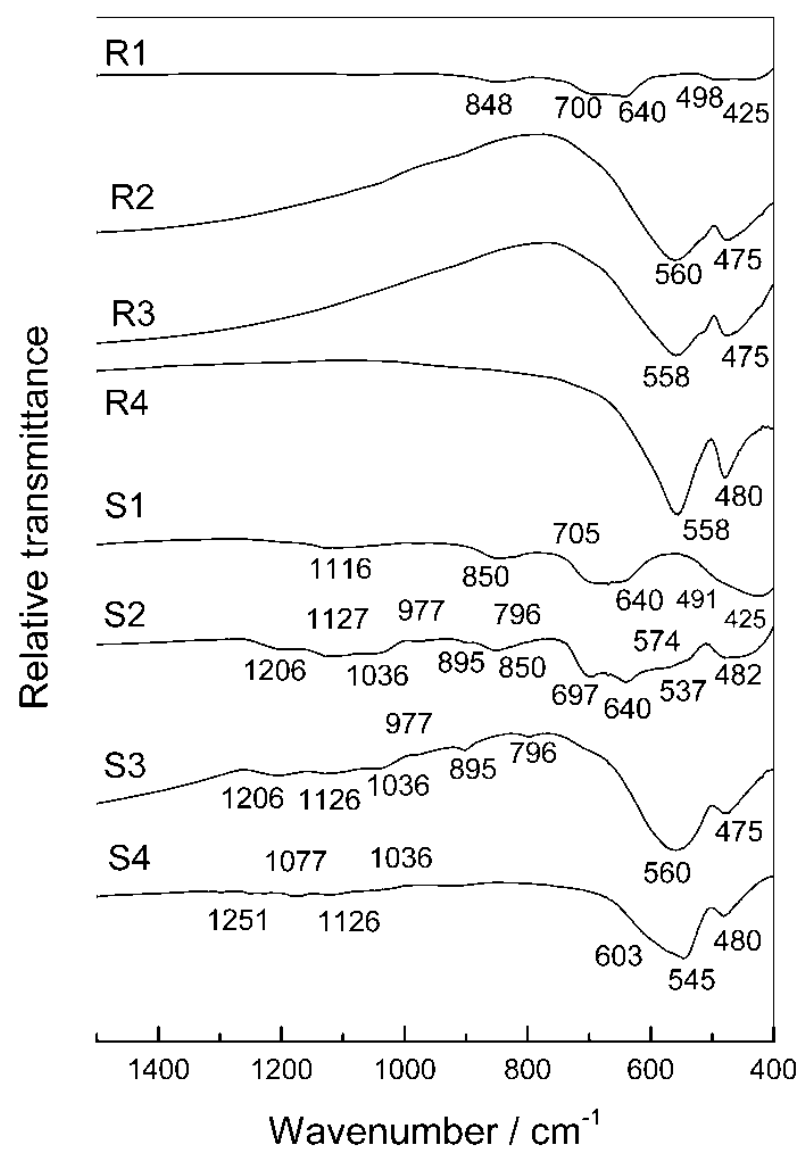

Figure 4. FT-IR spectra of reference samples R1 to R4 and samples $\mathrm{S} 1$ to $\mathrm{S} 4$.

Ocaňa et al. [22] precipitated spindle-shaped $\alpha-\mathrm{Fe}_{2} \mathrm{O}_{3}$ particles by the forced hydrolysis of the $\mathrm{Fe}\left(\mathrm{ClO}_{4}\right)_{3}$ solution at $100{ }^{\circ} \mathrm{C}$. The phosphate anions that could not be washed out were responsible for 
the formation of these particles morphology. The adsorbed phosphates were visible in the IR spectrum as evidence, with several peaks between 1036 and $934 \mathrm{~cm}^{-1}$.

Mössbauer, XRD and FT-IR measurements showed a direct phase transformation $\beta$-FeOOH $\rightarrow$ $\alpha-\mathrm{Fe}_{2} \mathrm{O}_{3}$ in reference samples $(\mathrm{R})$ produced by the forced hydrolysis of the $0.2 \mathrm{M} \mathrm{FeCl}_{3}$ solution. In the presence of SDS (samples S1 to S4) the kinetics of this phase transformation is retarded and in samples S2 and S3 produced between 6 and 24 hours of forced hydrolysis a small fraction of an intermediate phase $\alpha-\mathrm{FeOOH}$ is detected. Kandori et al. [12] assigned the formation of $\alpha-\mathrm{FeOOH}$ phase due to SDS addition in $\mathrm{FeCl}_{3}-\mathrm{HCl}$ hydrolysing solutions $(\mathrm{HCl}$ concentration was fixed; $\log (\mathrm{HCl})=-2.50)$. Musić et al. [23] investigated the effect of $\mathrm{HCl}$ additions on forced hydrolysis of $\mathrm{FeCl}_{3}$ solutions. These authors found that under the certain conditions the forced hydrolysis of $\mathrm{FeCl}_{3}$ solution containing only $\mathrm{HCl}$ additions may also produce $\alpha$ $\mathrm{FeOOH}$ phase. Wang et al. [24] investigated the precipitation of $\alpha-\mathrm{Fe}_{2} \mathrm{O}_{3}$ nanoparticles by the forced hydrolysis of $\mathrm{FeCl}_{3}$ solutions with no additive presence. In dependence on the experimental conditions primary nanoparticles showed different morphologies. It was also reported that beside the $\beta-\mathrm{FeOOH}$ $\rightarrow \alpha-\mathrm{Fe}_{2} \mathrm{O}_{3}$ phase transformation there was also a direct phase transformation of the amorphous fraction into $\alpha-\mathrm{Fe}_{2} \mathrm{O}_{3}$.

In the present work, the addition of SDS to the precipitation system caused the formation of a small fraction of $\alpha-\mathrm{FeOOH}$ as an intermediate phase, and between 6 and $72 \mathrm{~h}$ of autoclaving the HMF value of $\alpha-\mathrm{Fe}_{2} \mathrm{O}_{3}$ varied from 48.5 to $50.7 \mathrm{~T}$. These values of HMF are significantly decreased in relation to $51.75 \mathrm{~T}$ measured for well-crystalline $\alpha$ $\mathrm{Fe}_{2} \mathrm{O}_{3}$, as reported by Murad and Johnston [25]. It can be concluded that the presence of SDS lowers the crystallinity of precipitated $\alpha-\mathrm{Fe}_{2} \mathrm{O}_{3}$.

The FE SEM image of sample R1 (Figure 5a) showed mainly the presence of $\beta$-FeOOH rods, but star- and $\mathrm{X}$-shaped particles were also noticed. Sample R2 showed micron size $\alpha-\mathrm{Fe}_{2} \mathrm{O}_{3}$ particles (Figure 5b) which consisted of primary $\alpha-\mathrm{Fe}_{2} \mathrm{O}_{3}$ nanoparticles, as evidenced by Figure 5c. $\alpha-\mathrm{Fe}_{2} \mathrm{O}_{3}$ particles produced upon $72 \mathrm{~h}$ of the forced hydrolysis of $\mathrm{FeCl}_{3}$ solutions at $160{ }^{\circ} \mathrm{C}$ (sample $\mathrm{R} 4$ ) are shown in Figure 6a. These particles also showed the substructure (Figure 6b); however, the primary $\alpha-\mathrm{Fe}_{2} \mathrm{O}_{3}$ particles increased in size. The agglomera- tion of $\beta-\mathrm{FeOOH}$ nanorods (sample $\mathrm{S} 1$ ) is visible in Figure $7 \mathrm{a}$. Figures 7 b,c show big (micron size) particles of sample S4 of near spherical and peanuttype shapes, which possess the substructure and consist of fine, elongated (1D) primary $\alpha-\mathrm{Fe}_{2} \mathrm{O}_{3}$ particles (Figure 7c).

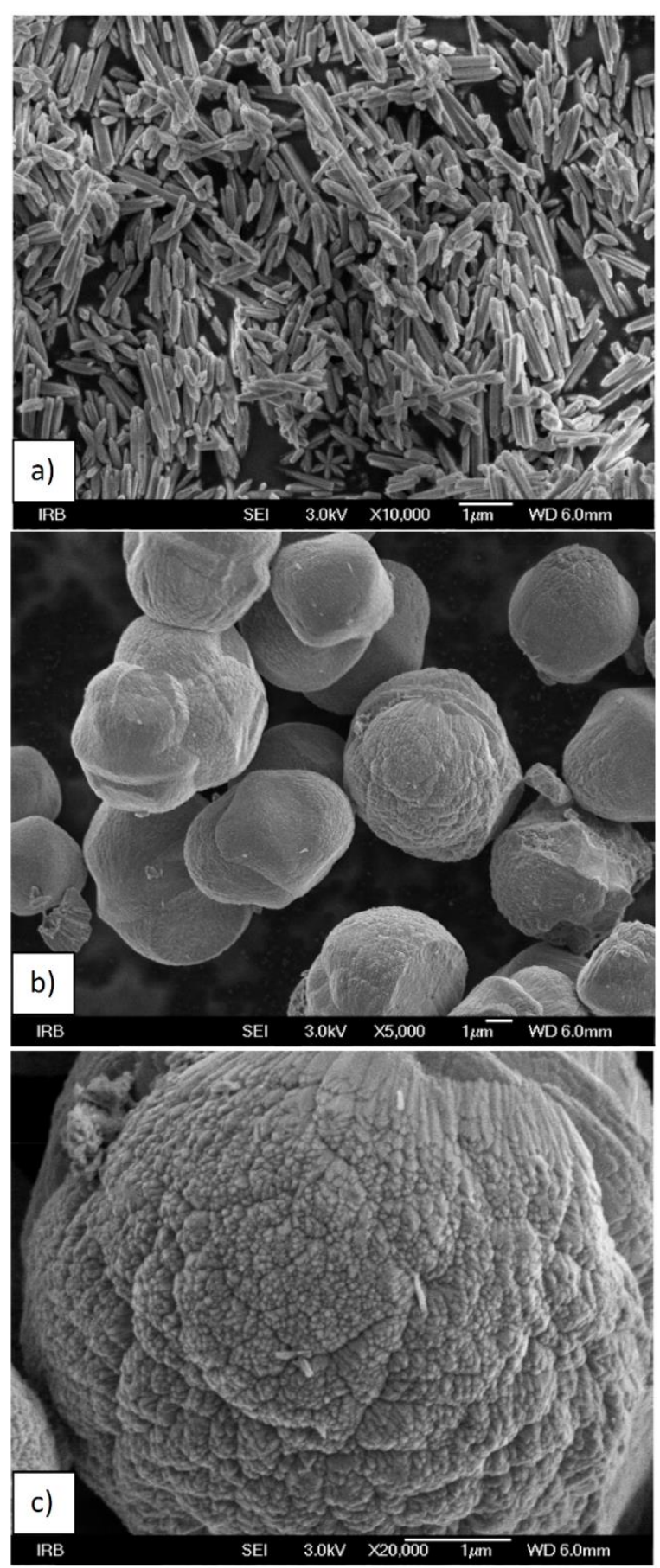

Figure 5. FE SEM images of samples: (a) R1 and (b, c) R2. 

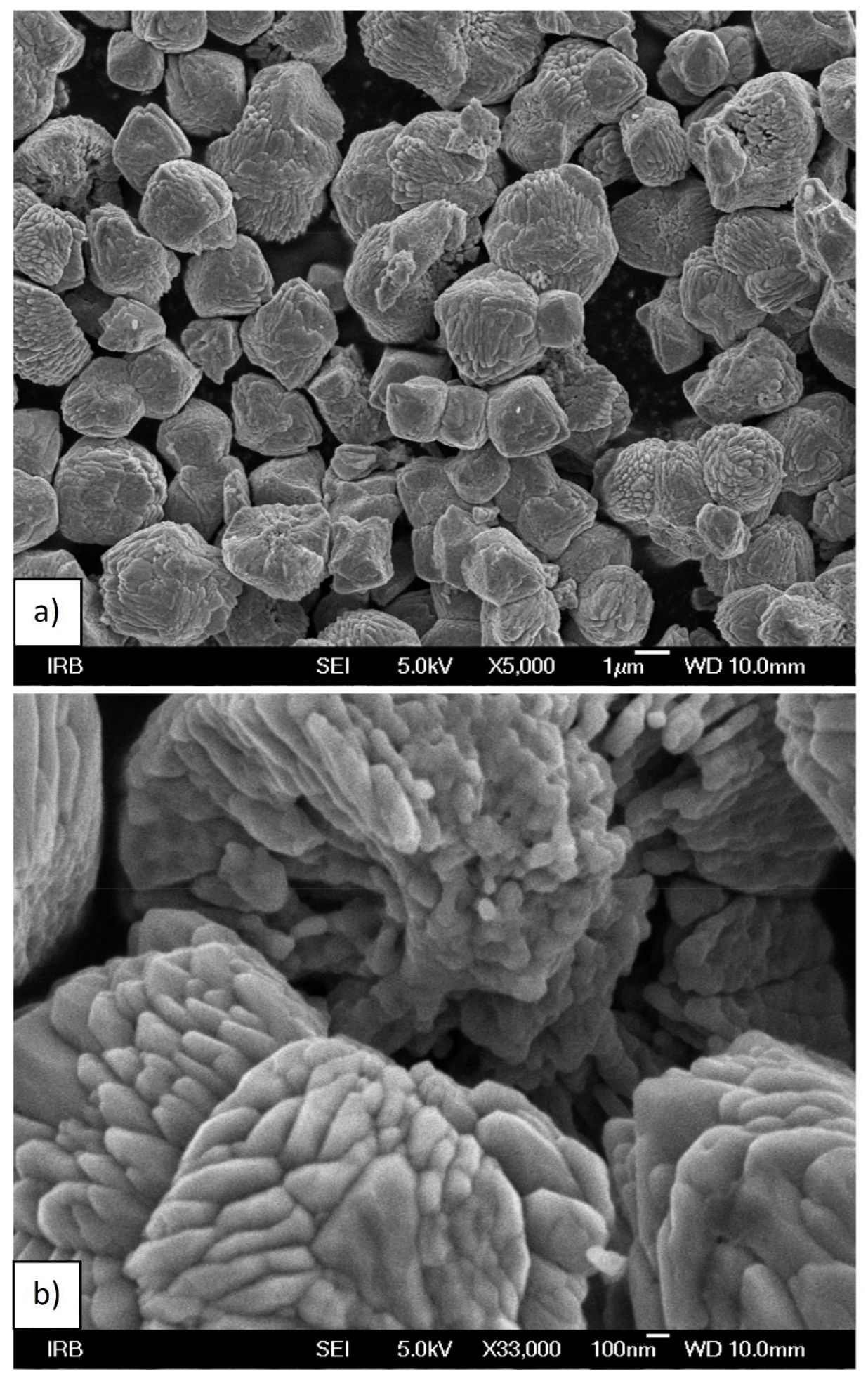

Figure 6. FE SEM images of reference samples R4 at different magnifications. 

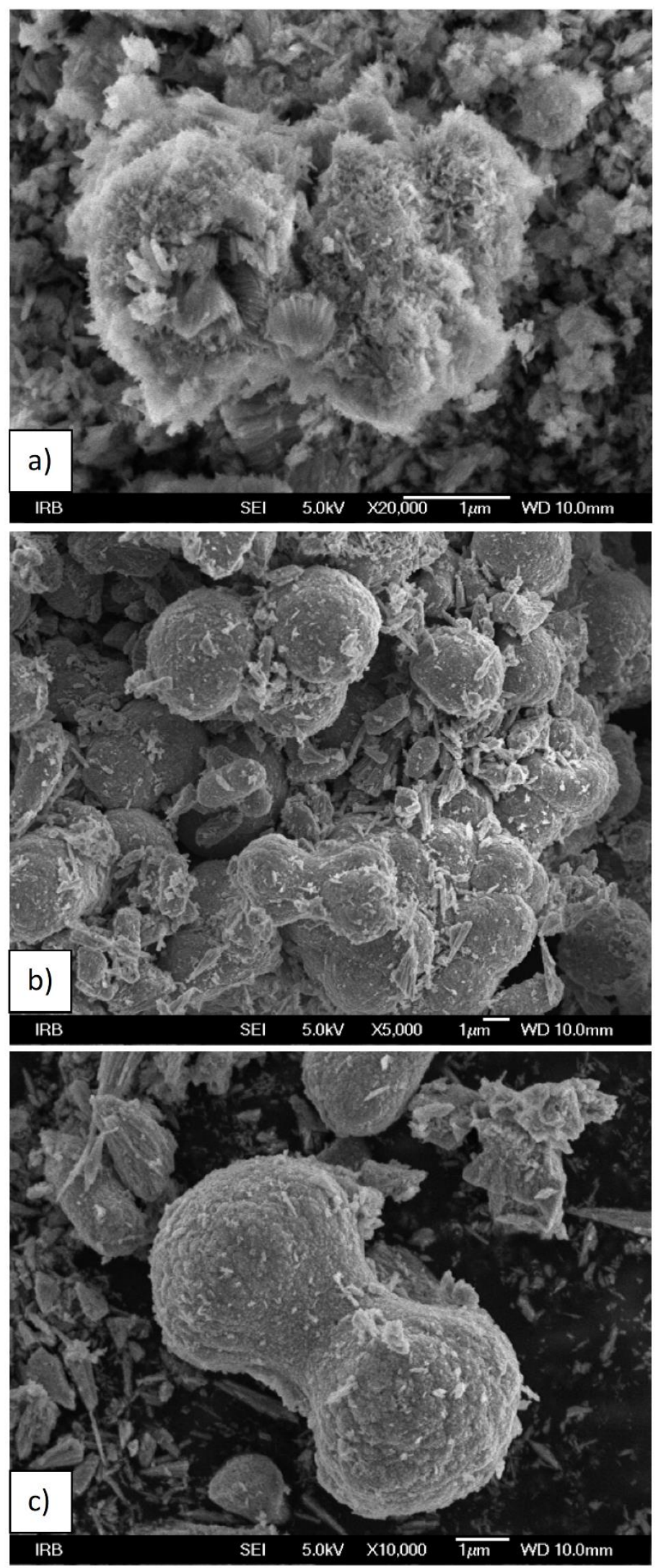

Figure 7. FE SEM images of samples: (a) S1 and (b, c) S4. The samples were precipitated in the presence of SDS. 


\section{CONCLUSION}

The effect of SDS (1\%) on the kinetics, phase composition and shape of the particles precipitated by the forced hydrolysis of the $0.2 \mathrm{M}$ $\mathrm{FeCl}_{3}$ solution was investigated. A direct phase transformation $\beta-\mathrm{FeOOH} \rightarrow \alpha-\mathrm{Fe}_{2} \mathrm{O}_{3}$ via dissolution/recrystallization was present in the absence of SDS. In the presence of SDS a small fraction of $\alpha$ $\mathrm{FeOOH}$ precipitated, which transformed to the end product $\alpha-\mathrm{Fe}_{2} \mathrm{O}_{3}$ also via the dissolution/recrystallization mechanism. $\alpha-\mathrm{Fe}_{2} \mathrm{O}_{3}$ particles precipitated in the presence of SDS showed lower crystallinity in relation to reference samples, as concluded on the basis of Mössbauer spectra. This effect was explained by the competition between the stability of $\mathrm{Fe}(\mathrm{III})$-dodecyl sulphate on one side and the formation of iron oxide phases on the other side. Precipitated $\alpha-\mathrm{Fe}_{2} \mathrm{O}_{3}$ particles showed the substructure, i.e., consisted of much smaller primary particles. The effect of SDS on the microstructure of $\alpha-\mathrm{Fe}_{2} \mathrm{O}_{3}$ particles is noticed. The influence of SDS on the forced hydrolysis of $\mathrm{FeCl}_{3}$ solutions can be related to the specific adsorption of sulphate groups on the nuclei and crystallites of $\mathrm{FeOOH}$ and $\alpha-\mathrm{Fe}_{2} \mathrm{O}_{3}$ phases. The specific adsorption of dodecyl sulphate groups was evidenced by FT-IR.

Acknowledgement. This work was supported by the Croatian Science Foundation: project No. IP-201606-8254.

\section{REFERENCES}

[1] J. R. Freyer, A. Gildawie, R. Paterson, High resolution studies of the initial stages of precipitation of hydrous iron oxides, Eight Int. Congress on Electron Microscopy, Canberra, 1974, Vol. 1, pp. 708-709.

[2] J. M. Gonzáles-Calbet, M. A. Alario-Franco, M. Gayoso-Andrade, The porous structure of synthetic akaganeite, J. Inorg. Nucl. Chem., 43 (1981), pp. 257-264.

[3] S. Musić, A. Vértes, G. W. Simmons, I. CzakóNagy, H. Leidheiser Jr., Mössbauer spectroscopic study of the formation of Fe(III)-oxyhydroxides and oxides by hydrolysis of aqueous Fe(III) salt solutions, J. Coll. Interface Sci., 85 (1982), pp. 256-266.

[4] E. Matijević, P. Scheiner, Ferric hydrous oxide sols. III. Preparation of uniform particles by hydrolysis of $\mathrm{Fe}(\mathrm{III})$-chloride, -nitrate, and -perchlorate solutions, J. Coll. Interface Sci., 63 (1978), pp. 509-524.

[5] S. Hamada, E. Matijević, Ferric hydrous oxide sols. IV. Preparation of uniform cubic hematite particles by hydrolysis of ferric chloride in alcohol-water solutions, J. Chem. Soc. Faraday Trans., I 78 (1982), pp. 2147-2156.

[6] E. K. De Blanco, M. A. Blesa, S. J. Liberman, Comments on the mechanism of the akageneitehematite phase transformation in hydrothermal solutions, Reactivity of Solids, 1 (1986), pp. 189-194.

[7] S. Musić, M. Ristić, S. Krehula, ${ }^{57} \mathrm{Fe}$ Mössbauer spectroscopy in the investigation of the precipitation of iron oxides, Chapter in the book Mössbauer Spectroscopy: Applications in Chemistry, Biology and Nanotechnology, Edited by V. K. Sharma, G. Klingelhofer and T. Nishida, Publ. by John Wiley \& Sons, 2013, pp. 470-504.

[8] H. Katsuki, S. Komarneni, Role of $\alpha-\mathrm{Fe}_{2} \mathrm{O}_{3}$ morphology on the color of red pigment for porcelain, J. Am. Ceram. Soc., 86 (2003), pp. 183-185.

[9] T. Sugimoto, Y. Wang, H. Itoh, A. Muramatsu, Systematic control of size, shape and internal structure of monodisperse $\alpha-\mathrm{Fe}_{2} \mathrm{O}_{3}$ particles, Colloids Surfaces A: Physicochem. and Eng. Aspects, 134 (1998), pp. 205-279.

[10] B. Mao, Z. Kang, E. Wang, C. Tian, Z. Zhang, C. Wang, Y. Song, M. Li, J. Solid State Chem., 180 (2007), pp. 489-495.

[11] K. Kandori, N. Hori, T. Ishikawa, Preparation of mesoporous hematite particles by a forced hydrolysis reaction accompanying a peptide production reaction, Colloids Surfaces: Physicochem. Eng. Aspects, 290 (2006), pp. 280-287.

[12] K. Kandori, I. Hori, A. Yasukawa, T. Ishikawa, Effect of surfactants on the precipitation and properties of colloidal particles from forced hydrolysis of $\mathrm{FeCl}_{3}-\mathrm{HCl}$ solutions, J. Mater. Sci., 30 (1995), pp. 2145-2152.

[13] M. Žic, M. Ristić, S. Musić, Microstructural changes in particles detected during the transformation from $\beta$-FeOOH to $\alpha-\mathrm{Fe}_{2} \mathrm{O}_{3}$ in dense aqueous suspensions, J. Alloys Comp., 464 (2008), pp. 81-88.

[14] M. Žic, M. Ristić, S. Musić, Precipitation of $\alpha$ $\mathrm{Fe}_{2} \mathrm{O}_{3}$ from dense $\beta$-FeOOH suspensions with added ammonium amidosulfonate, J. Mol. Struct. 924-926 (2008), pp. 235-242.

[15] S. Musić, A. Šarić, S. Popović, Effects of urotropin on the formation of $\beta-\mathrm{FeOOH}, J$. Mol. Struct. 410-411 (1997), pp. 153-156.

[16] A. Šarić, S. Musić, K. Nomura, S. Popović, Microstructural properties of $\mathrm{Fe}$-oxide powders obtained by precipitation from $\mathrm{FeCl}_{3}$ solutions, Mater. Sci. Eng., B56 (1998), pp. 43-52.

[17] B. Weckler, H. D. Lutz, Lattice vibration spectra. Part XCV. Infrared spectroscopic studies on the iron oxide hydroxides goethite (a), akageneite (b), lepidocrocite (d) and feroxyhite (d), Eur. J. Solid State Inorg. Chem., 35 (1998), pp. 531-544. 
[18] E. Murad, J. L. Bishop, The infrared spectrum of synthetic akageneite, $\beta-\mathrm{FeOOH}$, Am. Mineral., 85 (2000), pp. 716-721.

[19] Y. Wang, A. Muramatsu, T. Sugimoto, FTIR analysis of well-defined $\alpha-\mathrm{Fe}_{2} \mathrm{O}_{3}$ particles, Colloid Surf. Sci. A: Physicochem. Aspects, 134 (1998), pp. 281-297.

[20] S. Krehula, S. Musić, Influence of ageing in an alkaline medium on the microstructural properties of $\alpha-\mathrm{FeOOH}$, J. Cryst. Growth, 310 (2008), pp. 513-520.

[21] D. Peak, R. G. Ford, D. L. Sparks, An in situ ATR-FTIR investigation of sulfate bonding mechanisms on goethite, J. Coll. Interface Sci., 218 (1999), pp. 289-299.
[22] M. Ocaňa, M. P. Morales, C. J. Serna, Homogeneous precipitation of uniform $\alpha-\mathrm{Fe}_{2} \mathrm{O}_{3}$ particles from iron salts solutions in the presence of urea, $J$. Coll. Interface Sci. 212 (1999), pp. 317-323.

[23] S. Musić, S. Krehula, S. Popović, Effect of $\mathrm{HCl}$ additions on forced hydrolysis of $\mathrm{FeCl}_{3}$ solutions, Mater. Lett., 58 (2004), pp. 2640-2645.

[24] W. Wang, J. Y. Howe, B. Gu, Structure and morphology evolution of hematite $\left(\alpha-\mathrm{Fe}_{2} \mathrm{O}_{3}\right)$ nanoparticles in forced hydrolysis of ferric chloride, $J$. Phys. Chem., C 112 (2008), pp. 9203-9208.

[25] E. Murad, J. H. Johnston, Iron oxides and oxyhydroxides, in: G. J. Long (Ed.), Mössbauer Spectroscopy Applied to Inorganic Chemistry, 2, Plenum Pub. Corp. 1987, pp. 507-582.

\title{
ЕФЕКТОТ НА НАТРИУМ ДОДЕЦИЛ СУЛФАТ ВРЗ ПРИСИЛНАТА ХИДРОЛИЗА НА РАСТВОРИ НА $\mathrm{FeCl}_{3}$
}

\author{
Mira Ristić ${ }^{1}$, Jasenka Štajdohar ${ }^{1}$, Ivana Opačak ${ }^{2}$, Svetozar Musić ${ }^{1}$ \\ ${ }^{1}$ Институт „Руѓер Бошковиќ“, Загреб, Хрватска \\ ${ }^{2}$ Природно-математички факултет, Универзитет во Сплит, Хрватска
}

Изучувани се преципитациите при присилна хидролиза на воден раствор од $0.2 \mathrm{M} \mathrm{FeCl}_{3}$ за времетраење од 2 до 72 часа во присуство на 1\% натриум додецил сулфат (SDS). Во отсуство на SDS во преципитациониот систем доаѓа до директна фазна трансформација $\beta-\mathrm{FeOOH} \rightarrow \alpha-\mathrm{Fe}_{2} \mathrm{O}_{3}$ преку механизмот растворање/прекристализација. Во присуство на SDS, $\alpha-\mathrm{FeOOH}$ како интермедијарна фаза преципитира, а со продолжено време на присилна хидролиза исто така се трансформира во $\alpha-\mathrm{Fe}_{2} \mathrm{O}_{3}$ преку механизам на растворање/прекристализација. Врз основа на Месбауеровите (Mössbauer) спектри е заклучено дека во присуство на SDS фазата на $\alpha-\mathrm{Fe}_{2} \mathrm{O}_{3}$ поседува понизок степен на кристалност. Во овој преципитационен процес, важна улога игра и компетицијата помеѓу стабилноста на Fe(III)-додецил сулфатот, од една страна, и формирањето на фазите од оксидите на железото, од друга страна. FE SEM покажа дека крупните честички на $\alpha-\mathrm{Fe}_{2} \mathrm{O}_{3}$ поседуваат супструктура. Забележано е издолжување на примарните честички на $\alpha-\mathrm{Fe}_{2} \mathrm{O}_{3}$ добиени во присуство на SDS. Овој ефект може да му се припише на преферираната атсорпција на додецил сулфатните групи врз нуклеусите и кристалитите од $\mathrm{FeOOH}$ и фазата на $\alpha-\mathrm{Fe}_{2} \mathrm{O}_{3}$ во текот на присилната хидролиза на растворите на $\mathrm{FeCl}_{3}$.

Клучни зборови: $\mathrm{FeCl}_{3}$ хидролиза; натриум додецил сулфат; $\alpha-\mathrm{Fe}_{2} \mathrm{O}_{3}$; Mecбаyep (Mössbauer); FT-IR; XRD; FE SEM 
